Studia i materiały z dziedzictwa kulturowego Torunia i regionu, t. 1: STARE I NOWE DZIEDZICTWO TORUNIA,

Toruń 2013

http://dx.doi.org/10.12775/SiMzDzKTiR_T1.2013.010

Jan Tajchman

(IZIK UMK, TORUŃ)

\title{
Toruńskie elewacje w typie tzw. Domu Kopernika Pamięci kolegów: Jerzego Frycza i Feliksa Polakowskiego*
}

Dom przy ul. Kopernika 17 w Toruniu przez ponad sto lat był uznawany za miejsce urodzenia Mikołaja Kopernika. Otaczano go wielkim „kultem”, co wpłynęło także na zakres prac konserwatorsko-restauratorskich przeprowadzonych na początku lat 60. ubiegłego wieku. W niniejszym artykule ${ }^{1}$ przyjęto określenie „tzw. Dom Kopernika”, ponieważ dziś wiadomo już, że nie w nim przyszedł na świat ten wielki torunianin. Jego ojciec, także Mikołaj, był w tym okresie właścicielem dwóch domów: obok kamienicy przy obecnej ul. Kopernika 17 pod nr 15 oraz w Rynku Staromiejskim pod nr $36^{2}$, gdzie obecnie znajduje się dom towarowy.

Nim zajmiemy się gotyckimi elewacjami w typie, jaki odkryto przy ul. Kopernika pod nr 17 warto wspomnieć, iż „kult” miejsca urodzenia tego wielkiego astronoma rozpoczął się już od około 1760 roku, lecz nie pod obecnym numerem 17, ale w domu na rogu ul. Koziej (obecnie Piekary) i Starotoruńskiej (obecnie Kopernika 40). Na temat tego „kultu” warto za Jerzym Fryczem przytoczyć pewne ciekawostki³ ${ }^{3}$ W 1807 roku dom ten nawiedził Napoleon Bonaparte, co zostało uwiecznione na miedziorycie wykonanym przez Adama Pilińskiego (il. 1). W czasach Księstwa Warszawskiego generał Woyczyński, ówczesny komendant miasta, cegiełkę z tego domu przekazał Izabeli Czartoryskiej do Puław, która wmurowała ją uroczyście w Świątyni Sybilli. W 1825 r. dom ten odwiedził też piętnastoletni wówczas Fry-

\footnotetext{
*Jerzy FRYCZ opracował dokumentację historyczną w 1960 roku oraz artykuł w 1963 roku o kamienicy pod nr 17 traktując ją jako dom narodzin Mikołaja Kopernika (patrz przypis nr 3) oraz był autorem koncepcji rekonstrukcji szczytu tego domu. Felicjan POLAKOWSKI był autorem projektu architektoniczno-konserwatorskiego domu pod nr 17 a potem projektu adaptacji obu kamienic (15 i 17) na Muzeum Kopernika.

Materiały ilustracyjne do tego artykułu przygotowali komputerowo Marek Gogolin, Tomasz Kalinowski, Ewa Bożejewicz.

2 Krzysztof MIKULSKI, Watzenrodowie i dom rodzinny Mikołaja Kopernika w Toruniu, [w:] Studia nad dziejami miast i mieszczaństwa w średniowieczu, Studia ofiarowane Profesorowi Antoniemu Czacharowskiemu w sześćdziesiątą piąta rocznicę urodzin i czterdziestolecie pracy naukowej, red. R. CZAJA i J. TANDECKI, Toruń 1996, s. 254.
}

3 Jerzy FRYCZ, Dom Kopernika w Toruniu, „Rocznik Muzeum w Toruniu”, t. 1, 1963, s. 134-150. 
deryk Chopin, a swe wrażenia z tego miejsca opisał w liście do przyjaciela, Jana Matuszyńskiego, tymi słowy:

Wszakżeś widział w Sybilli cegiełkę wyjęta z domu Kopernika, z miejsca jego urodzenia? A ja widziałem cały ten dom, całe to miejsce, lubo teraz nieco sprofanowane. Wystaw sobie, Kochany Jasiu, w owym kacie, w tym pokoju, gdzie ten sławny astronom życiem uradowany został, stoi łóżko jakiegoś Niemca, który pewnie objadtszy się kartofli, nieraz dość częste puszcza zefiry, a po owych cegiełkach, z których jedna z wielkim ceremoniałami do Puław posłano, niejedna łazi pluskiewka. Tak to, mój Bracie! Niemiec nic nie zważa, kto w tym domu mieszkał; dopuszcza się tego na całą ścianę, czego by Xiężna Czartoryska na jedną nie zrobiła cegiełkę.

W 1849 roku budynek ten został przebudowany ${ }^{4}$. Mimo głosów krytycznych, podważających pewność tej tradycji, to w nim w 1871 roku Towarzystwo Coppernicus-Verein wmurowało niemieckie tablice ku czci astronoma. W roku $1881 \mathrm{r}$. historyk, a zarazem burmistrz Georg Bender, na podstawie analizy materiałów archiwalnych Torunia ustalił, że wbrew dotychczasowym poglądom, Mikołaj Kopernik urodził się w domu pod nr 17. W 1923 roku umieszczono na tej kamienicy tablicę w języku polskim, wspomnianą tablicę niemiecką z domu pod nr 40 zdjęto jednak dopiero w 1938 roku. W ten sposób przez jakiś czas były w Toruniu dwa domy urodzin Kopernika: polski i niemiecki. W czasie okupacji hitlerowcy usunęli tablicę polską, a niemiecką powiesili na powrót na budynku pod nr 40. W 1945 roku ponownie ją zdjęli i zabrali ze sobą. Ukryta tablica z napisem w języku polskim powróciła na budynek pod nr 17 i funkcjonowała tak do czasu przeprowadzenia odkrywek na elewacji w 1960 roku.

W 1955 roku stanowisko Georga Bendera w sprawie identyfikacji miejsca narodzin astronoma poparł prof. Karol Górski ${ }^{5}$. Stało się to podstawą do adaptacji w 1960 roku kamienicy pod nr 17 na Muzeum Mikołaja Kopernika, które rozszerzono w roku 1973 roku o sąsiednia kamienicę pod nr 15 (il. 2). W 1986 roku prof. Tomasz Jasiński ${ }^{6}$ zakwestionował jednak stanowisko poprzedników i udowodnił, że ojciec astronoma był właścicielem domu obok, czyli pod nr 15 oraz przy Rynku Staromiejskim pod nr 36 (obok kamienicy Pod Gwiazdą) - czyli posiadał dwa domy. W 1996 roku tezę Jasińskiego potwierdził prof. Krzysztof Mikulski . Uczeni ci skłaniają się również do stwierdzenia, że Mikołaj Kopernik urodził się w budynku przy Rynku Staromiejskim.

Gotycka forma obu domów przy ul. Kopernika oraz długa tradycja decydują o tym, że to w nich nadal mieści się muzeum astronoma. W niniejszym artykule zajmiemy się natomiast analizą fasady domu pod nr 17 oraz kolejnych elewacji o tym samym schemacie kompozy-

4 Kolejne wzmianki historyczne w:g FRYCZ 1963, s. 138-139.

5 Karol GÓRSKI, Dom Kopernika w Toruniu, „Ochrona Zabytków”, t. 6, z. 1, 1953; TENŻE, Domostwa Mikołaja Kopernika $w$ Toruniu, Towarzystwo Bibliofilów im. Lelewela w Toruniu, Toruń 1995; TENŻE, Dom i środowisko rodzinne Mikołaja Kopernika, Toruń 1972.

6 Tomasz JASIŃSKI, Dom rodzinny Mikołaja Kopernika. Przyczynek do studiów nad socjotopografia późnośredniowiecznego miasta, „Kwartalnik Historyczny”, t. 92, 1986, s. 861.

7 MIKULSKI 1996, s. 254. 
cyjnym. Posiadały je domy: przy ul. Mostowej 6, Mostowej 24, Łaziennej 5 oraz przy Rynku Staromiejskim 20.

Jak już wspomniano, kamienicę pod nr 17 przeznaczono na cele muzealne i zorganizowanie w niej wystawy kopernikańskiej. Z tym zamiarem miejski konserwator zabytków, Bohdan Rymaszewski, przystąpił w 1960 roku do częściowego remontu budowli, rozpoczynając od zbicia tynków ze zniekształconej klasycystycznej fasady z początku XIX wieku $(\text { il. } 3 \mathrm{~A})^{8}$. Oczom konserwatorów ukazały się fragmenty elewacji gotyckiej (malowanej na czerwono), niestety bez szczytu (il. 3B), lecz z resztkami polichromii maswerkowej w blendach i fryzach. W tamtym okresie była to wielka rewelacja. Po wstępnych zabezpieczeniach lica ścian i resztek polichromii elewację częściowo otynkowano.

Jeszcze w 1960 r. otwarto wystawę kopernikańską w budynku o tak zniszczonej elewacji, w której okna z okresu klasycyzmu kolidowały ze strukturą gotycką. Niestety, ówczesne władze nie pozwoliły na zamknięcie ekspozycji celem przeprowadzenia właściwych prac konserwatorsko-restauratorskich, gdyż otworzył ją sam ówczesny przewodniczący Rady Państwa. „Z pomocą” konserwatorom przyszedł jednak grzyb budowlany, który pojawił się po położeniu przez wykonawcę mokrych desek na starych belkach i przykryciu ich gumolitem ${ }^{9}$.

Projekt został wykonany przez Przedsiębiorstwo Państwowe Pracownie Konserwacji Zabytków (PP PKZ) ${ }^{10}$. Zachowane fragmenty gotyckiej elewacji bez większych trudności pozwoliły na przywrócenie fasadzie jej dawnej formy w obrębie parteru i pięter. Problem pojawił się dopiero przy szczycie, z którego zachowała się jedynie podstawa w formie kilku warstw cegieł gotyckich lizen oraz od wnętrza - ślady po linii dachu (il. 3C). Formę rekonstrukcji szczytu zaproponował Jerzy Frycz, stwierdzając:

Zachowane resztki podstawy wskazują, że był on podzielony na trzy blendy, z których środkowa była szersza od bocznych. Zróżnicowanie szerokości pozwala z kolei wnioskować o zróżnicowanej wysokości blend i schodkowym układzie szczytu ${ }^{11}$.

Prace przeprowadzono w latach 1962-63 ${ }^{12}$. Uzupełnienie elementów architektonicznych w obrębie parteru i pięter oraz rekonstrukcja szczytu, a także odtworzenie malowanej dekoracji w blendach i fryzach, przywróciły gotyckiej elewacji jej pełną formę $e^{13}$ (il. 3D). Za rekon-

8 FRYCZ 1963, s. 145 oraz Bohdan RYMASZEWSKI, Problematyka konserwatorska toruńskich kamienic, „Zeszyty Naukowe UMK", Zabytkoznawstwo i Konserwatorstwo, t. 1, 1966, s. 135.

9 Jest to jedyny znany przykład „pozytywnego” działania grzyba budowlanego, gdyż zmusił władze do wydania zgody na przeprowadzenie prac konserwatorsko-restauratorskich.

10 Autor projektu architektonicznego - Felicjan Polakowski, konstrukcji - Stanisław Miklaszewski.

11 FRYCZ 1963, s. 142.

12 Wykonawcą prac przy tej kamienicy, jak i przy następnych elewacjach były Pracownie Konserwacji Zabytków w Toruniu. W czasie tej realizacji przy ul. Kopernika 17 odtworzono także wielką sień, przekrywając ją profilowanymi gotyckimi belkami ze zniszczonego w czasie wojny budynku przy ul. Żeglarskiej 12 . W tylnym trakcie stropy pozostały na poziomie z okresu klasycyzmu, co wymagało zaprojektowania dość skomplikowanych schodów, łączących różne kondygnacje. Na przyszłość zaplanowano również połączenie obu budynków (15 i 17), które zrealizowano na rocznicę kopernikańską w 1973 roku (il. 2).

13 Aby nie uszkodzić oryginalnych resztek polichromii w blendach oddzielono je papierem i dopiero wtedy położono tynk na siatce. Na nim wykonano pełną rekonstrukcję polichromii maswerkowej. Blenda zachodnia na 
strukcja całej fasady łącznie z polichromia przemawiały przede wszystkim względy natury dydaktycznej ${ }^{14}$. Chciano pokazać społeczeństwu, jak wyglądał dom gotycki w czasach Kopernika - tym bardziej, że panowało przekonanie, iż to w nim urodził się wielki astronom.

Na ile propozycja schodkowej formy szczytu z wysokimi blendami była trafna, mogliśmy przekonać się dopiero w 1970 roku, kiedy to (bez wiedzy Miejskiego Konserwatora Zabytków) zbito tynki z elewacji domu przy ul. Mostowej 6 (il. 4 A, B). W jego południowym członie wyłoniła się fasada kamienicy o podobnej zasadzie kompozycyjnej, jak w domu przy ul. Kopernika 17, z zachowanym szczytem schodkowym o zróżnicowanej wysokości trzech blend, z tym że środkowa blenda zamknięta jest łukiem ostrym, a boczne łukami pełnymi, podczas gdy w kamienicy przy Kopernika 17 przyjęto wszystkie trzy łuki jako ostre. W domu przy ul. Mostowej 6 nie przetrwało niestety rozczłonkowanie elewacji parteru, jej teoretyczną rekonstrukcję oparto więc o rozwiązanie przyziemia domu przy ul. Kopernika 17. Parter ten jest także podobny do innych parterów fasad tego samego typu, z którymi zapoznamy się w dalszej kolejności. Pełne pokazanie fasady przy ul. Mostowej 6, po badaniach Ireneusza Sławińskiego, nie przedstawiało większej trudności ${ }^{15}$.

Analizując obie fasady (po dokonaniu teoretycznych rekonstrukcji) stwierdzamy, że należą one do rozwiązań o takich samych zasadach kompozycyjnych, które można scharakteryzować następująco:

Są to fasady trójstrefowe o prawie jednakowej wysokości stref zbliżonych do kwadratu - czyli o kompozycji ad quadratum (il. 4 C, D).

- Strefa pierwsza obejmująca wielką sień jest dwuosiowa z ostrołukowym portalem i dużym oknem w blendzie zamkniętej łukiem zbliżonym do pełnego;

- Strefa druga obejmująca pierwsze i drugie piętro jest trójosiowa z otworami okiennymi tylko w osiach bocznych, a z blendą (z blendami) w osi środkowej;

- $\quad$ Strefę trzecią stanowi trójosiowy szczyt schodkowy z wysokimi blendami.

Odkrycie trójosiowej fasady przy ul. Mostowej 6 w 1971 roku pozwoliło spojrzeć inaczej na elewacje domów, które dotychczas wyłoniły się spod tynków i posiadały podobnie zachowane otwory dolnej strefy. Najbardziej zbliżone rozwiązanie do elewacji domu przy ul. Kopernika 17 ma fasada kamienicy przy ul. Mostowej 24, której struktura ukazała się częściowo po zbiciu tynków (il. 5A). W 1972 roku badania architektoniczne i projekt uporządkowania elewacji wykonał Ireneusz Sławiński ${ }^{16}$. Uczytelnienie drugiej strefy nie nastręczało żadnych

murze granicznym i zachodni fragment fryzu nad parterem nie otrzymały polichromii, aby nie zacierać oryginalnych gotyckich rytów na tynku. Należy podkreślić, iż było to pierwsze w Toruniu odtworzenie tego typu malarstwa. Prace te w ramach PKZ wykonały Krystyna Dąbrowska i Joanna Kwiatkowska. Obecna polichromia maswerkowa jest już trzecim odtworzeniem tej kompozycji.

14 RYMASZEWSKI 1966, s. 139.

15 Opieramy się na badaniach wykonanych w 1971 r. przez I. Sławińskiego. W trakcie tych badań nie udało się wyjąć wypełnień z blend szczytu celem stwierdzenia, czy istniała tam polichromia. Jeżeli polichromia była zachowana na niższych kondygnacjach, to została zniszczona w 1970 r. przy zbijaniu tynków.

16 Ireneusz SŁAWIŃSKI, Badania architektoniczne elewacji frontowych dwóch budynków mieszkalnych przy ulicy Mostowej 24/26, PKZ Toruń 1972 [mps]. 
trudności, łącznie z restauracją maswerkowej polichromii w blendach i fryzach ${ }^{17}$ (il. 5B). Strefy pierwszej nie można było odtworzyć ze względu na konieczność przywrócenia wysokiej sieni, w której obecnie znajdują się dwie kondygnacje. Zachowane pozostałości pozwalają jednak na odtworzenie otworów parteru. Teoretyczna rekonstrukcja szczytu była możliwa na podstawie analogii do zwieńczenia budynku przy ul. Mostowej 6 (il. 5C). Obie elewacje kamienic - przy ul. Kopernika 17 i przy Mostowej 24 - posiadają wąskie blendy na murach granicznych; dom przy Kopernika po prawej, a przy Mostowej po lewej stronie (widoku). Świadczy to, że obie fasady były wykonane jednocześnie dla domów bliźniaczych, jako lustrzane odbicia. Tak też zostały pokazane na teoretycznych rekonstrukcjach (il. 6A, B) ${ }^{18}$.

W kamienicy przy ul. Łaziennej 5 zbito tynki w roku 1969 (il. 7A, B). Wyłoniły się wówczas fragmenty artykulacji gotyckiej fasady w dwóch pierwszych strefach. W obrębie parteru odsłonięto górną część portalu i górne zwieńczenie okna. W strefie pięter zachował się zarys lizen (niestety) tylko do podstawy łuków. Pełnych badań nie przeprowadzono. Inwentaryzację oraz projekt na jej podstawie wykonał Ireneusz Sławiński. Prace restauracyjne zostały przeprowadzone w 1970 roku (il. 7C). W ich ramach odtworzono częściowo strukturę gotyckiej elewacji, bez przywracania pierwotnych poziomów dawnych kondygnacji. Konieczność zachowania mieszkalnego poddasza w obrębie dawnego szczytu wymusiła zaprojektowanie nowego, z ceglanymi lizenami i tynkowanymi przestrzeniami. Dziś widać, że zwieńczenie kamienicy jest nieproporcjonalnie niskie w stosunku do niższych kondygnacji, mimo że jej forma jest próbą bardziej współczesnego, skromnego rozwiązania. Tylko blendzie środkowej przywrócono całkowitą głębokość. Wszystkie trzy blendy drugiej strefy zamknięto łukami ostrymi, co do których nie było moim zdaniem stuprocentowej pewności. Resztki cegieł u podstaw łuków przemawiały raczej za formą półkolistego zwieńczenia. Wybrano niestety łuki ostre, gdyż nie zdawano sobie jeszcze wtedy sprawy, iż w tym typie architektury tylko wyjątkowo stosowano łuki ostre w portalu i w środkowej, najwyższej części szczytu. W teoretycznej rekonstrukcji powrócono do pierwotnego poziomu podłogi parteru. Blendy drugiej strefy zamknięto łukami pełnymi. Ich wysokie pola mogły być prawdopodobnie podzielone poziomymi krótkimi fryzami, jak np. w kamienicy przy ul. Mostowej 24. Konsekwentnie łuki pełne zastosowano także nad bocznymi blendami szczytu.

Kamienica przy Rynku Staromiejskim 20 już w 1938 roku została pozbawiona tynków, spod których wyłoniła się jej ceglana struktura gotycka (il. 8A, B). W 1961 roku wykonano dokumentację projektową, według której nastąpiły dalsze odkrycia i częściowe uporządkowanie elewacji ${ }^{19}$. Po wyjęciu ceglanych zamurowań blend ukazała się gotycka struktura drugiej strefy (il. 8C), polegająca na rozczłonkowaniu elewacji głębokimi blendami, zamkniętymi od góry łukami odcinkowymi. Ten typ łuków jest odmienny od łuków pełnych

17 Konserwację i restaurację polichromii przeprowadził zespół PKZ w osobach: Krystyna Dąbrowska, Danuta Kowalewska, Anna Kwiatkowska.

18 Rekonstrukcję fasady domu bliźniaczego przy ul. Kopernika 17 (ze szczytami według Jerzego Frycza) przedstawił w swym artykule także Zbigniew NAWROCKI, Pięć kamienic przy ul. Kopernika w Toruniu, „Kwartalnik Architektury i Urbanistyki", t. 30, z. 1, 1985, il. 12 na s. 209.

19 Felicjan POLAKOWSKI, Stanisław MIKLASZEWSKI, Projekt techniczno-roboczy architektoniczno-konstrukcyjny kamienicy przy Rynku Staromiejskim 20, PKZ Toruń 1961 [mps]. 
lub do nich zbliżonych, jakie występują w omawianych dotychczas kamienicach, należy jednak do form miękkich. Podobnie jak w kamienicy przy ul. Kopernika 17 oraz Mostowej 6 i 24, środkowa blenda nie miała tu okien, lecz gotycką dekorację malarską o motywach geometrycznych, w tonacji szaro-niebieskiej. W czasie prac blendy tej nie odtworzono, gdyż nie pozwalał na to funkcjonalny układ pomieszczeń. Pod otworami okiennymi drugiego piętra znajduje się ceglany fryz ułożony rębem, przechodzący przez lizeny i blendy. Cała strefa środkowa została zamknięta od góry i od dołu płaskimi pasami fryzów (zapewne kiedyś polichromowanymi), ograniczonymi cegłami, ustawionymi rębem. Wszystkie te rębowe fryzy miały skuty profil. Ponieważ jego forma była nieznana, fryzy odtworzono z pełnych cegieł ustawionych w rolkę. Dopiero po skończeniu prac znaleziono cegłę okapnikową, jaką stosowano w gotyckich fryzach; niestety, fryzu nie zmieniono już na okapnikowy ${ }^{20}$.

Otwory okienne na drugim piętrze, zamknięte łukami płaskimi, posiadały haki po okiennicach - podobnie jak w domu przy ul. Kopernika 17. Świadczy to o magazynowym charakterze tej kondygnacji. Okna pierwszego piętra miały płaskie nadproża, a nad nimi zamurowania aż do łuków odcinkowych. W okresie gotyckim cała elewacja (lico cegieł wraz ze spoinami) była barwiona na czerwono, co odtworzono przy użyciu czerwieni żelazowej na bazie mleka wapiennego. Nie zdecydowano się na odtworzenie otworów parteru, mimo że zachowało się zwieńczenie ostrołuku portalu oraz odcinkowe przesklepienie okna (il. 8C). W trzeciej strefie zachowały się jedynie boczne lizeny szczytu, które przy ówczesnej wiedzy nie pozwalały na ich odtworzenie. Stało się to możliwe (naturalnie w formie teoretycznej) dopiero po analizie wszystkich pięciu elewacji kamienic (il. 8D).

Analizując rozwiązania tych pięciu fasad stwierdzamy, iż stanowią one wyodrębnioną grupę o wspólnych cechach generalnych, jak:

Trójstrefowość - niezależnie czy dotyczy to domów bliźniaczych (przy ul. Kopernika 17 i 19 oraz przy Mostowej 24 i 26), czy pojedynczych (domy przy Mostowej 6, Łaziennej 5, przy Rynku Staromiejskim 20).

- $\quad$ Pierwsza strefa, odpowiadająca wysokiej sieni, jest we wszystkich czterech fasadach (z wyjątkiem niezachowanego parteru przy Mostowej 6) dwuosiowa, z ostrołucznym portalem i z oknem we wnęce zwieńczonej łukiem, zbliżonym do pełnego ( $\mathrm{z}$ wyjątkiem łuku odcinkowego w parterze Rynku Staromiejskiego 20);

- Druga (środkowa) strefa, która zachowała się we wszystkich fasadach (odpowiadająca pierwszemu i drugiemu piętru) jest trójosiowa, z otworami okiennymi w osiach bocznych oraz blendami w osi środkowej. W tych trzech osiach ukształtowane są wnęki, biegnące przez dwie kondygnacje i są zamknięte łukami pełnymi lub do nich zbliżonymi, a w przypadku domu przy Rynku Staromiejskim 20 - nawet odcinkowym. W kamienicy przy ul. Mostowej 6 blendy zamknięte łukami pełnymi, oddzielnie dla każdej kondygnacji, tworzą wyraźny podział piętrowy, podczas gdy ten podział w pozosta-

20 Przyjęto wtedy bardzo ortodoksyjne założenie, że jeżeli nie wiadomo, jaki był profil, to wystarczy jedynie ustawić cegłę rębem. Ogólnie wiadomo, że we fryzach i gzymsach stosowano przeważnie cegłę okapnikową. Ze względów historycznych zastosowano fryzy w formie rolki. Są one tępe i wyglądają bardzo źle; warto by je zmienić przy planowanych obecnie pracach. 
ych kamienicach zaznaczony jest w formie dość różnorodnie ukształtowanych fryzów. W konsekwencji, strefa środkowa jest w generaliach jednakowa we wszystkich pięciu kamienicach. Różnice dotyczą szczegółów odróżniających je minimalnie;

- $\quad$ Strefa trzecia (wieńcząca) zachowała się tylko w kamienicy przy ul. Mostowej 6. Jest ona także trójosiowa, ze środkową blendą wyższą, zamkniętą łukiem ostrym oraz dwiema bocznymi, niższymi, o łukach pełnych, tworzących schodkowy szczyt.

Takie samo ogólne rozwiązanie strefy dolnej (parterowej) czterech z omówionych fasad oraz zbliżone ukształtowanie strefy środkowej wszystkich elewacji, upoważnia nas do przyjęcia założenia, iż strefa wieńcząca w niezachowanych szczytach posiadała także środkowe blendy, zamknięte łukiem ostrym oraz blendy niższe, boczne, zamknięte takimi samymi łukami, jak w strefie środkowej, tworząc wszędzie szczyty schodkowe. Tak też przedstawiono je na rysunkowych rekonstrukcjach (il. 6 i 9).

Datowanie architektury omawianych fasad nie jest łatwe, gdyż brak jest możliwości bezpośrednich porównań. Jerzy Frycz datował fasadę domu przy ul. Kopernika 17 (hipotetycznie, jak sam się zastrzegał) na lata 80 . XV wieku ${ }^{21}$. Ireneusz Sławiński stwierdził, że elewacja domu przy Mostowej 6 powstała przed połową XV wieku (może nawet po 1415 r.) $)^{22}$. Szczyty schodkowe z blendami stosowano w Toruniu już około połowy XIV wieku ${ }^{23}$. Utrzymywały się one bardzo długo, stąd nie mogą stanowić podstawy porównań. Podobnie nie można brać pod uwagę strefy pierwszej, gdyż ostrołukowy portal zestawiany jest z dużym oknem (oknami) w okresie całego gotyku.

Najważniejszym elementem porównań, zmierzających do datowania elewacji omawianych kamienic, jest ich strefa środkowa, odpowiadająca tzw. stylowi miękkiemu. W tym przypadku warto zwrócić uwagę na spostrzeżenia Adama Miłobędzkiego:

Już na przełomie XIV i XV wieku styl miękki przyniósł odrodzenie półkola; $w$ architekturze ziem krzyżackich elementy półkola pojawiają się nawet około 1370 roku we wschodnim szczycie fary w Brodnicy. W ostatniej ćwierci XV wieku w ceglanym budownictwie północnej Europy pótkola i prostokątne podziały coraz częściej wypierały ostrołuk, doprowadzając do wyodrębnienia osobnego nurtu późnego gotyku operującego wyłacznie miękkimi formami, m.in. w szczytach i attykach ${ }^{24}$.

W architekturze sakralnej ziemi chełmińskiej XIV wieku zasadniczo nie spotyka się łuków kolistych (do wyjątków należy Brodnica). Łuki pełne i do nich zbliżone występują natomiast w drugiej połowie XIV wieku w architekturze świeckiej Torunia. Spotykamy ich niewiele, gdyż większość budynków gotyckich nie dotrwała do naszych czasów. Na podstawie dendrochronologicznych badań konstrukcji dachów można wydatować następujące

21 FRYCZ 1966, s. 140.

22 SŁAWIŃSKI 1971.

23 Eugeniusz GĄSIOROWSKI, Toruńska kamienica mieszczańska, „Zeszyty Naukowe UMK”, Zabytkoznawstwo i Konserwatorstwo, t. 1, 1966, s. 90.

24 Adam MIŁOBĘDZKI, Późnogotyckie typy sakralne w architekturze ziem polskich, [w:] Późny gotyk. Studia nad sztuka przełomu średniowiecza i czasów nowych, Warszawa 1965, s. 103. 
kamienice o łukach pełnych lub do nich zbliżonych: ul. Wielkie Garbary 7 - około $1360 \mathrm{roku}^{25}$, ul. Żeglarska 10 - około 1350 roku, ul. Mostowa 24 - około 1395 roku (il. 5) ${ }^{26}$. Ponadto łuki pełne znajdowały się na nieistniejących fasadach: Dworu Artusa, datowanego na około 1385 rok oraz Ratusza Nowomiejskiego z drugiej połowy XIV wieku (il. 10) ${ }^{27}$. Gmachem, posiadającym dużą różnorodność łuków (poza ostrymi) jest Ratusz Staromiejski, którego rozbudowa nastąpiła po 1393 roku. Są to łuki pełne, koszowe i odcinkowe (il. 10). Eugeniusz Gąsiorowski, wymieniając te formy, stwierdził:

Łuki takie występuja w średniowiecznych domach toruńskich około 1400 przejęte być może z architektury flamandzkiej, gdzie motyw ten pojawia się już w końcu XIII wieku ${ }^{28}$.

Istnieją także w Toruniu kamienice o wysokich blendach zamkniętych łukami pełnymi. Datuje się je na początek XV wieku, przyjmując oddziaływanie podobnego rozczłonkowania Ratusza Staromiejskiego - mimo, że posiada on zamknięcie blend ostrołukami. Przykładem są kamienice przy ul. Łaziennej 3 i na Małych Garbarach 4.

Andrzej Grzybkowski zauważył, iż początki niderlandyzmu na Pomorzu są związane z pierwszymi budowlami gotyckimi ${ }^{29}$. Odnośnie do Ratusza Staromiejskiego w Toruniu, zjawisko to dostrzegli tacy badacze, jak: Artur Semrau, Karl Gruber i Gwido Chmarzyński, a potwierdził je Eugeniusz Gąsiorowski w monografii ratusza, wyjaśniając jednocześnie, na czym polegały kontakty mieszczan toruńskich z Brugią. Kupcy toruńscy zajmowali się dalekosiężnym handlem hurtowym. Posiadali odpowiednią renomę na rynkach zagranicznych i odgrywali dużą rolę w działalności Hanzy. Pełnili także ważne funkcje we władzach kantoru brugijskiego, a potem niektórzy z nich byli nawet burmistrzami Torunia. Kontakty z Brugią nie ograniczały się do małej grupy przedstawicieli miasta. W drugiej połowie XIV wieku około stu pięćdziesięciu kupców toruńskich trudniło się handlem morskim, prowadzonym bezpośrednio z Brugią. Aż czterdzieści osiem procent obrotów handlowych należało do rajców. Statki morskie dopływały Wisłą do Torunia, często przywożąc flamandzkich gości ${ }^{30}$. Te kontakty przełożyły się zapewne nie tylko na architekturę ratusza, ale oddziałały także na rozwiązania wielu kamienic, w tym także tych pięciu, prezentowanych w niniejszym artykule.

W pierwszej połowie XV wieku w architekturze świeckiej Torunia łuki pełne i im podobne występują razem z łukami ostrymi oraz niejednokrotnie równocześnie z blendami pro-

25 Jan TAJCHMAN, Konstrukcje więźb dachowych w średniowiecznej architekturze murowanej Pomorza - komunikat z badań, „Kwartalnik Architektury i Urbanistyki”, t. 47, z. 1, 2002, s. 71.

26 Aleksander KONIECZNY, Ekspertyza dendrochronologiczna Mostowa 24, Żeglarska 10, Toruń 2007 [mps w zbiorach MKZ w Toruniu].

27 Toruń i miasta ziemi chełmińskiej na rysunkach Jerzego Fryderyka Steinera z pierwszej połowy XVIII w., red. M. BISKUP, Toruń 1998, s. 215 i 210.

28 Eugeniusz GĄSIOROWSKI, Ratusz Staromiejski w Toruniu, Toruń 2004, s. 64.

29 Andrzej GRZYBKOWSKI, Niderlandyzm w gotyckiej architekturze pomorskiej, [w:] Niderlandyzm w sztuce polskiej, materiały Sesji Stowarzyszenia Historyków Sztuki, Toruń, grudzień 1992, red. T. HRANKOWSKA, Warszawa 1995, s. 279.

30 GĄSIOROWSKI 2004, s. 51. 
stokątnymi. Przykładem takiej symbiozy jest dom bliźniaczy (zamieniony później na spichlerz) przy ulicy Piekary 4, powstały (według badania dendrochronologicznego) około $1400 \mathrm{roku}^{31}$. Posiada on ostrołukowe portale oraz otwory okienne o łukach pełnych, a także prostokątne blendy, obejmujące dwie górne kondygnacje. Podobnie budynek przy ulicy Świętego Ducha 8/10 na rogu z ulicą Kopernika, wzniesiony po $1430 \mathrm{roku}^{32}$, ma na parterze dość duże blendy zamknięte łukami pełnymi, w których znajdują się prostokątne okna. Dwie górne kondygnacje budowli obejmują prostokątne blendy, w których na pierwszym piętrze występują okna prostokątne, a na drugim zamknięte łukiem odcinkowym. Kamienicą, w której ta symbioza łuków występuje aż do końca gotyku, jest wreszcie dom przy ul. Rabiańskiej 8, ukończony dopiero po 1539 roku $^{33}$.

Podsumowując nasze rozważania, możemy z całym przekonaniem stwierdzić, iż pięć omawianych kamienic mogło powstać na początku XV wieku. Zbudowano je według dość jednolitej koncepcji architektonicznej, operując już przy tym detalem charakterystycznym dla tzw. miękkiego stylu gotyckiego. Aby dokładniej określić czas budowy tych kamienic, należy wziąć pod uwagę wyniki dendrochronologicznego badania więźby dachowej kamienicy przy ulicy Mostowej 24: powstała ona po $1395 \mathrm{roku}^{34}$. Dopiero po tej dacie można było zrealizować pokrycie dachu i wreszcie - wykończenie całego domu. Wynika stąd, iż kamienica został wzniesiona około 1400 roku; można zatem przyjąć, że pozostałe domy zbudowano także krótko przed lub po tej dacie.

Należy stwierdzić, że rozwiązanie omawianych fasad jest kompozycją stosowaną lokalnie dla domów średniej wielkości o trzech osiach - podobnych przykładów nie znamy ani z literatury, ani z autopsji. Na przykład w Lubece - gdzie można byłoby się spodziewać najbardziej zbliżonych elewacji - operowano zupełnie innymi rozwiązaniami, dość często powtarzając swoje schematy. Możemy zatem mówić o panującej w Toruniu około 1400 roku miejscowej modzie kształtowania pewnego typu kompozycji fasad kamienic za pomocą twórczo zastosowanego detalu, przejętego zwłaszcza z architektury niderlandzkiej.

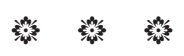

\section{Toruń Merchants' houses in the so called Copernicus House type}

Merchants' house at 17 Copernicus Street (Kopernika) in Torun for over a hundred years has been considered a place of Nicolaus Copernicus birth. That is why the undertaken works revealed from beneath the $19^{\text {th }}$ century plasters a Gothic façade, unfortunately with no gable,

31 Andrzej ZIELSKI, Konstrukcje ciesielskie w średniowiecznej architekturze Pomorza - datowanie dendrochronologiczne, IZiK UMK, Toruń 2002 [mps].

32 Aleksander KONIECZNY, Ekspertyza dendrochronologiczna, Świętego Ducha 8/10 [mps] w zbiorach MKZ Toruń.

33 Aleksander KONIECZNY, Ekspertyza dendrochronologiczna, Rabiańska 8 [mps w zbiorach MKZ Toruń].

34 Aleksander KONIECZNY, Ekspertyza dendrochronologiczna, Mostowa 24 [mps w zbiorach MKZ Toruń]. 
that has been reconstructed (fig. 3). The most properly - as it turned out after some years, when the façade at 6 Bridge St. (Mostowa) was revealed (fig. 4). Subsequent discoveries: at 24 Bridge St. (fig. 5), at 5 Bath St. (Łazienna, fig. 7) and at 20 Old Town Market Square (Rynek Staromiejski; fig. 8) testified, that there was a certain type of late-Gothic façades in Torun.

After theoretical reconstruction of missing elements one could ascertain, that those five façades had been arranged following quite a uniform composition scheme (fig. $4 \mathrm{D}$ ).

They are three-zoned façades with almost square zones of similar height: the first zone, corresponding with the Grand Hall of the house was two-axial with an ogival portal and a large window; second (middle) zone comprising the first and the second floors was three-axial with shallow recesses closed with rounded arch. Windows were located only in side axes. The third zone is a three-axial stepped gable, where a middle recess was closed with pointed arch, and side recesses with rounded ones, as in the second zone. Partly preserved side (fourth) recesses in houses at 17 Copernicus St. and 24 Bridge St. bear the witness of the houses being twin ones (fig. 6). The other houses were single ones (fig. 9). The prevailing architectonic forms of those houses were soft, late-Gothic ones, that had developed in Torun lay architecture in early 15th century under the Netherlandish influence (fig. 11). Thus the façades could have been erected ca. 1400. For one of them, i.e. 24 Bridge St. it was possible to date the preserver roof structure. According to the results of dendrochronological investigation the rafter frame was built after 1395, that seems to prove the assumed dating of the house. 


\section{SPIS ILUSTRACJI:}

1. Miedzioryt A. Pilińskiego przedstawiający domniemany dom M. Kopernika, który stał na rogu ulic Piekary i Kopernika, fot. wg N. MAZURKIEWICZ, Mikołaj Kopernik, Toruń 2000, s. 6

2. Toruń, oddział Muzeum Okręgowego w Toruniu (Dom Kopernika), składający się z budynku pod nr. 15 z ok. 1370 r. i pod nr. 17, ok. 1395 r., fot. A. Skowroński

3. Toruń, kamienica przy ul. Kopernika 17 (tzw. Dom Kopernika). A - elewacja przed zbiciem tynku; B - po zbiciu tynku; C - rekonstrukcja teoretyczna; D - realizacja w 1973 roku, fot. A, B,C wg FRYCZ 1966, s. 135-139, D - A. Skowroński.

4. Toruń, kamienica przy ul. Mostowej 6. A - przed zbiciem tynków; B - segment południowy po zbiciu tynków; C - rekonstrukcja teoretyczna; D - schemat kompozycji fasady, fot. A - wg R. HEUER, Thorn, Berlin 1931, B - J. Tajchman, C, D, oprac. J. Tajchman.

5. Toruń, kamienica przy ul. Mostowej 24. A - elewacja po zbiciu tynków; B - Elewacja po pracach w 1970 r.; C - rekonstrukcja teoretyczna dla czasu po 1395 r., fot. A - PKZ Toruń, B - J. Tajchman, C - oprac. J. Tajchman.

6. Rekonstrukcje teoretyczne. A - Kopernika 17/19, około 1400 r.; B - Mostowa 24/26, po 1395 r., oprac. J. Tajchman

7. Toruń, kamienica przy ul. Łaziennej 5. A - po zbiciu tynków w 1969 r.; B - Inwentaryzacja; C - Po pracach 1972 r.; D - Rekonstrukcja teoretyczna, fot. A - PKZ Toruń, B - I. Sławiński, C - J. Tajchman, D - oprac. J. Tajchman.

8. Toruń, Rynek Staromiejski 20. A - Stan przed zbiciem tynków przed 1938 r.; B - Stan po zbiciu tynków 1938 r.; C - elewacja po pracach 1962 r.; D - Rekonstrukcja teoretyczna, fot. A - wg Z. BALEWSKI, Album ikonografii m. Torunia, t. III, Widoki fragmentów miasta. Widoki ulic, część 1, Toruń 1981, foto nr 13, B - PKZ Toruń, C - J. Tajchman, D - oprac. J. Tajchman.

9. Rekonstrukcje teoretyczne. A - Mostowa 6; B - Łazienna 5; C - Rynek Staromiejski 20,oprac. J. Tajchman.

10. A - Dwór Artusa około 1385 r.; B - Ratusz Nowomiejski w II poł. XIV w.; C - Żeglarska 10 po pracach. Wybudowana około 1350 r.; D, E, F - Ratusz Staromiejski, detale, po 1393 r., fot. A, B wg Toruń i miasta ziemi chełmińskiej na rysunkach Jerzego Fryderyka Steinera z pierwszej połowy XVIII w., red. M. Biskup, Toruń 1998, il. 59 i 44; C, D, E, F - J. Tajchman.

11. A - Brugia. Kantor Angielski. Koniec XIV w.; B - Brugia, wieża hal targowych, około 1300 r.; C - Brugia, przedstawicielstwo kupców genueńskich, około 1399 r.; D - Dom celny, 1. poł. XIV w., fot. A wg E. Pilecka, Średniowieczne Dwory Artusa w Prusach, Toruń 2005, il. 50; B, C, D - E. Pilecka. 


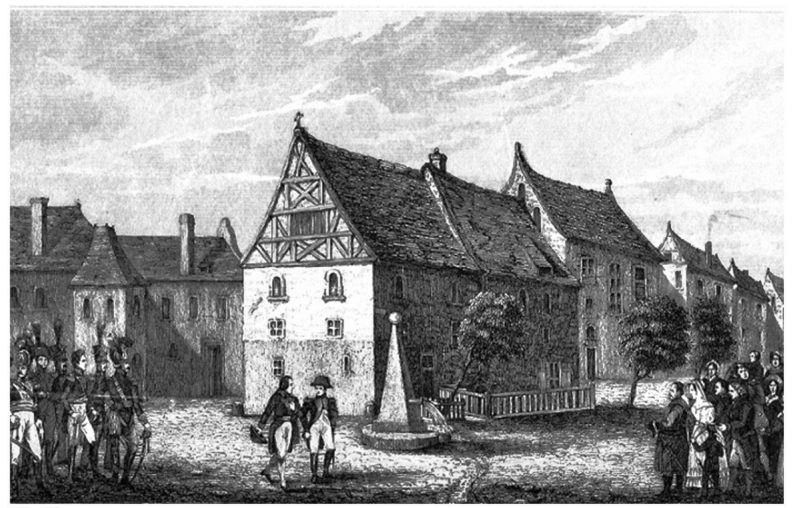

\section{Il. 1}

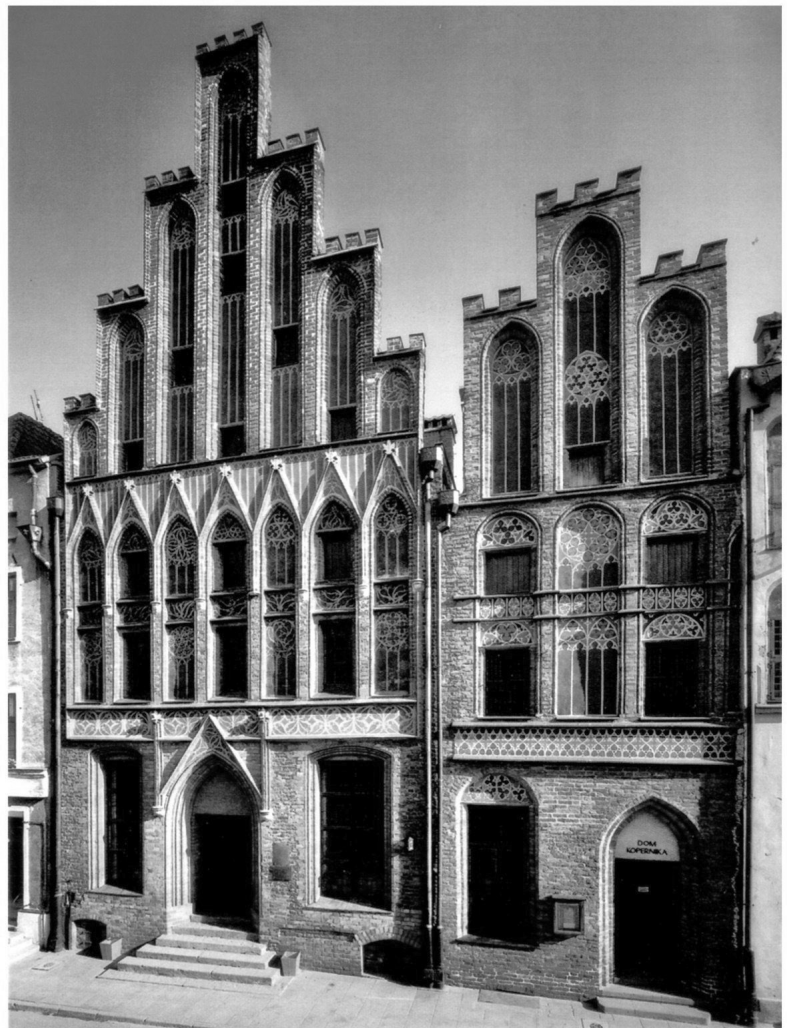

Il. 2

Il. 1 Miedzioryt A. Pilińskiego przedstawiający domniemany dom M. Kopernika, który stał na rogu ulic Piekary i Kopernika, fot. wg N. MAZURKIEWICZ, Mikołaj Kopernik, Toruń 2000, s. 6

Il. 2 Toruń, oddział Muzeum Okręgowego w Toruniu (Dom Kopernika), składający się z budynku pod nr. 15 z ok. 1370 r. i pod nr. 17, ok. 1395 r., fot. A. Skowroński 

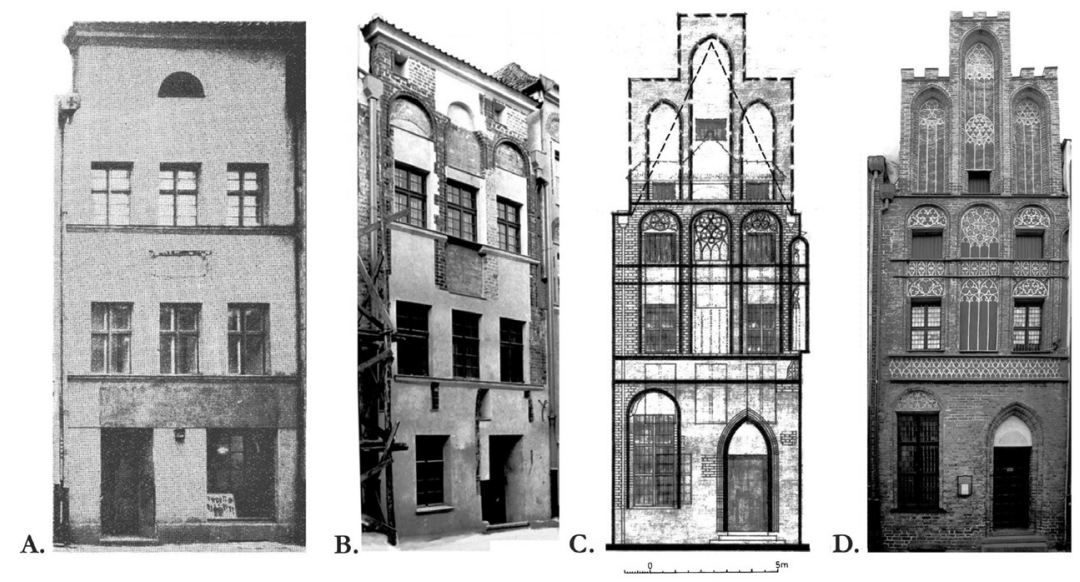

Il. 3

Il. 3 Toruń, kamienica przy ul. Kopernika 17 (tzw. Dom Kopernika). A - elewacja przed zbiciem tynku; B - po zbiciu tynku; C - rekonstrukcja teoretyczna; D - realizacja w 1973 roku, fot. A, B, C - wg FRYCZ 1966, s. 135-139, D - A. Skowroński

A.

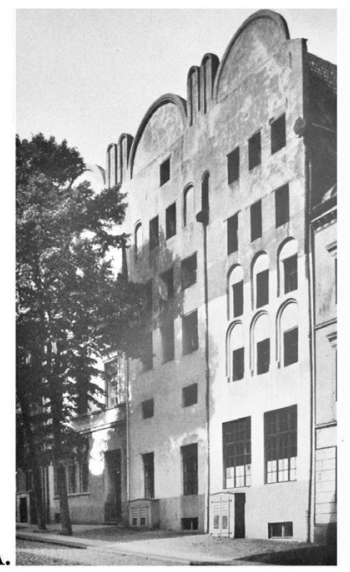

I1. 4
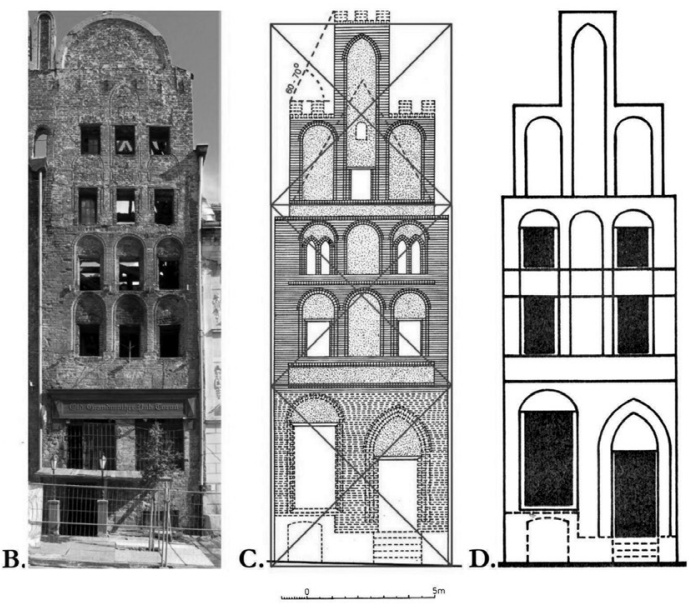

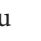




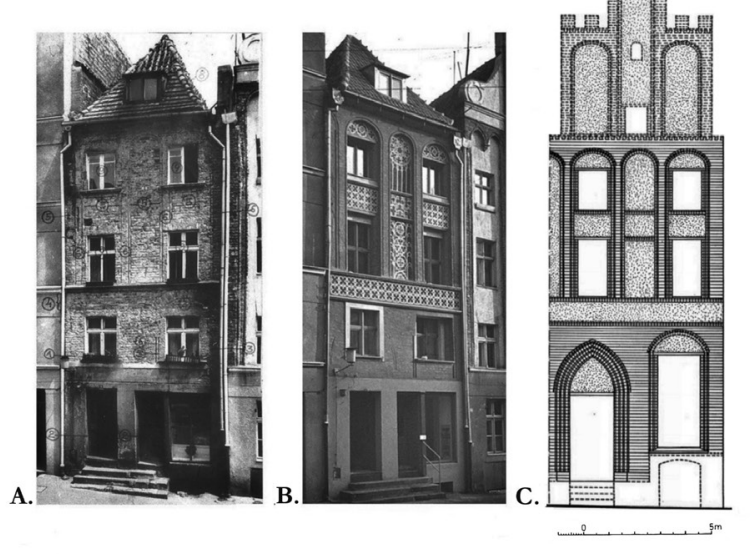

I1. 5

Il. 5 Toruń, kamienica przy ul. Mostowej 24. A - elewacja po zbiciu tynków; B - Elewacja po pracach w 1970 r.; C - rekonstrukcja teoretyczna dla czasu po 1395 r., fot. A - PKZ Toruń, B - J. Tajchman, C - oprac. J. Tajchman
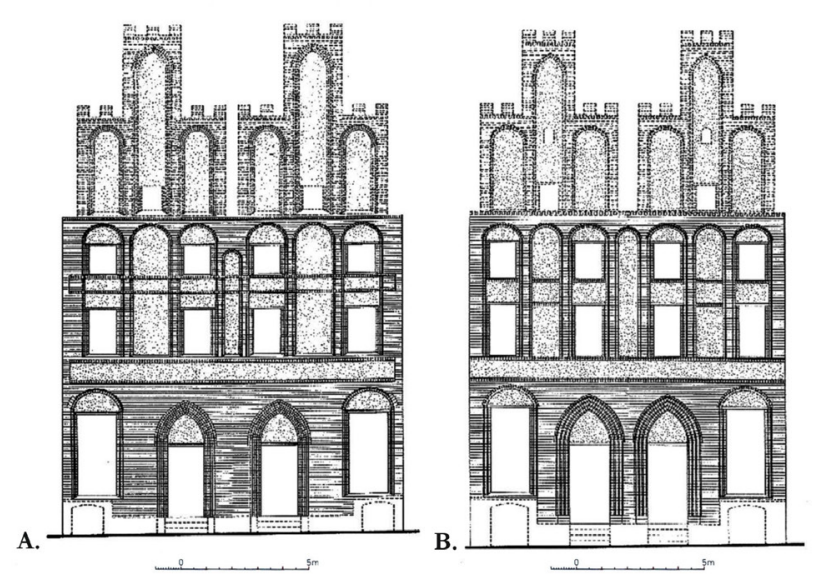

I1. 6

Il. 6 Rekonstrukcje teoretyczne. A - Kopernika 17/19, około 1400 r.; B - Mostowa 24/26, po 1395 r., oprac. J. Tajchman 

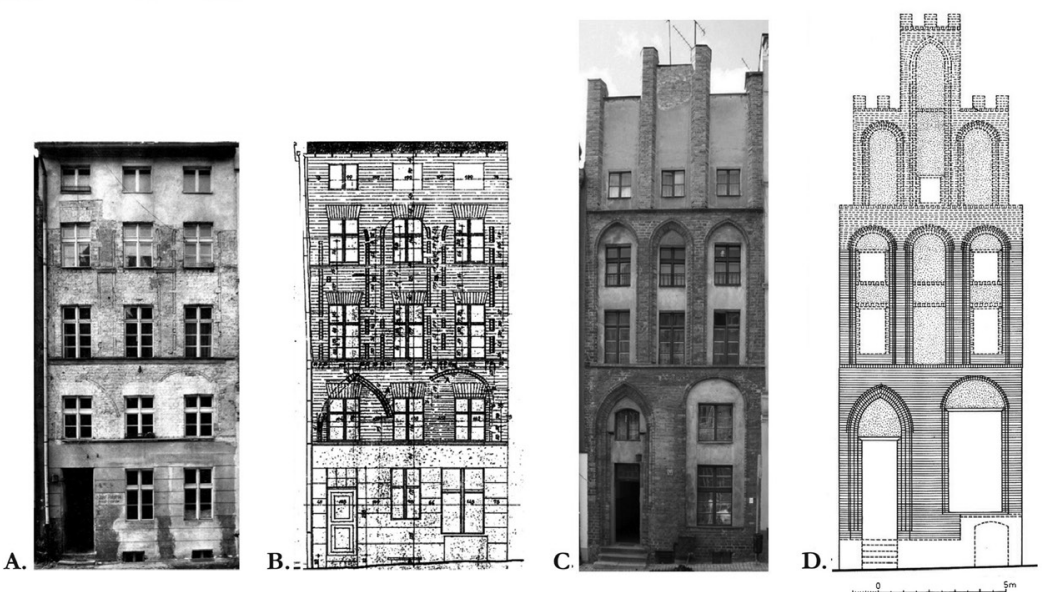

Il. 7

Il. 7 Toruń, kamienica przy ul. Łaziennej 5. A - po zbiciu tynków w 1969 r.; B - Inwentaryzacja; C - Po pracach 1972 r.; D - Rekonstrukcja teoretyczna, fot. A - PKZ Toruń, B - I. Sławiński, C - J. Tajchman, D - oprac. J. Tajchman
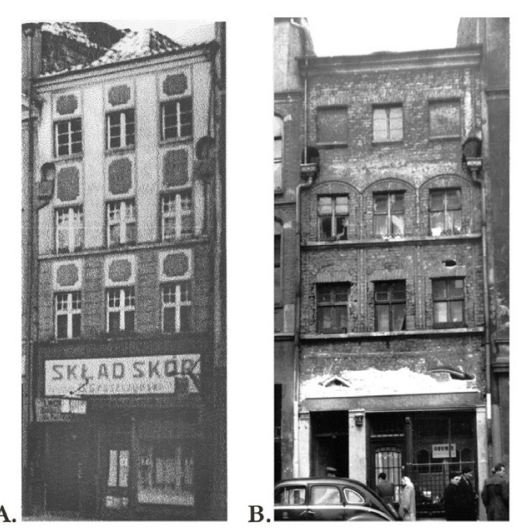

I1. 8
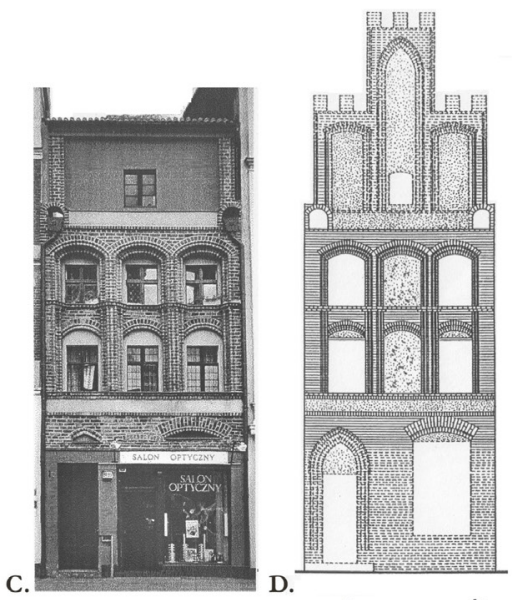

D.

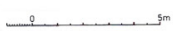

Il. 8 Toruń, Rynek Staromiejski 20. A - Stan przed zbiciem tynków przed 1938 r.; B - Stan po zbiciu tynków 1938 r.; C - elewacja po pracach 1962 r.; D - Rekonstrukcja teoretyczna, fot. A - wg Z. BALEWSKI, Album ikonografii m. Torunia, t. III, Widoki fragmentów miasta. Widoki ulic, część 1, Toruń 1981, foto nr 13, B - PKZ Toruń, C - J. Tajchman, D - oprac. J. Tajchman 

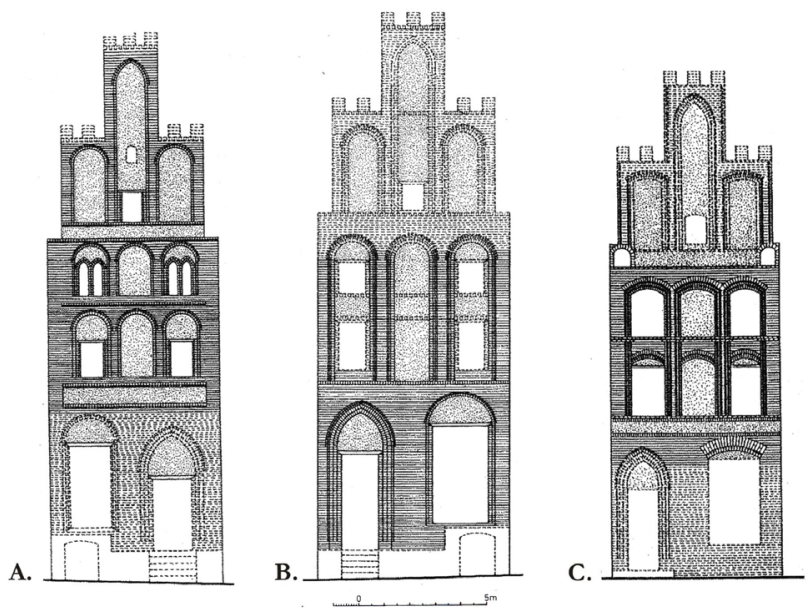

II. 9

Il. 9 Rekonstrukcje teoretyczne. A - Mostowa 6; B - Łazienna 5; C - Rynek Staromiejski 20, oprac. J. Tajchman

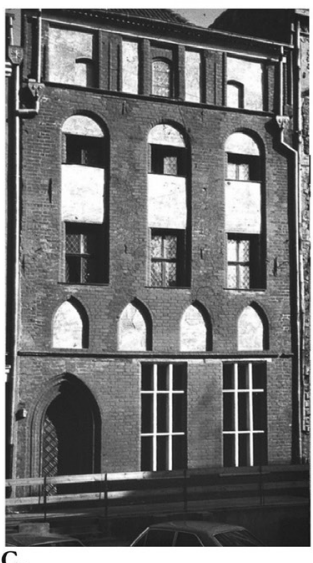

C.

Il. 10
A.

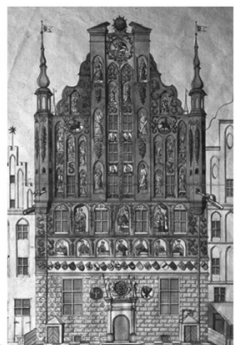

B.

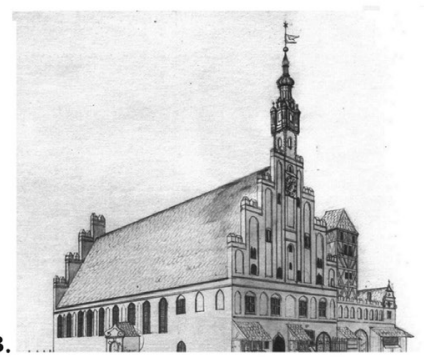

D.

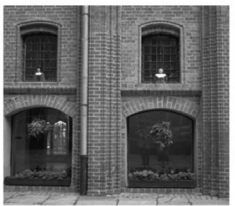

E.

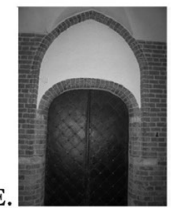

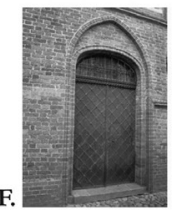

Il. 10 A - Dwór Artusa około 1385 r.; B - Ratusz Nowomiejski w II poł. XIV w.; C - Żeglarska 10 po pracach. Wybudowana około 1350 r.; D, E, F - Ratusz Staromiejski, detale, po 1393 r., fot. A, B wg Toruń i miasta ziemi chełmińskiej na rysunkach Jerzego Fryderyka Steinera z pierwszej połowy XVIII w., red. M. Biskup, Toruń 1998, il. 59 i 44; C, D, E, F - J. Tajchman 

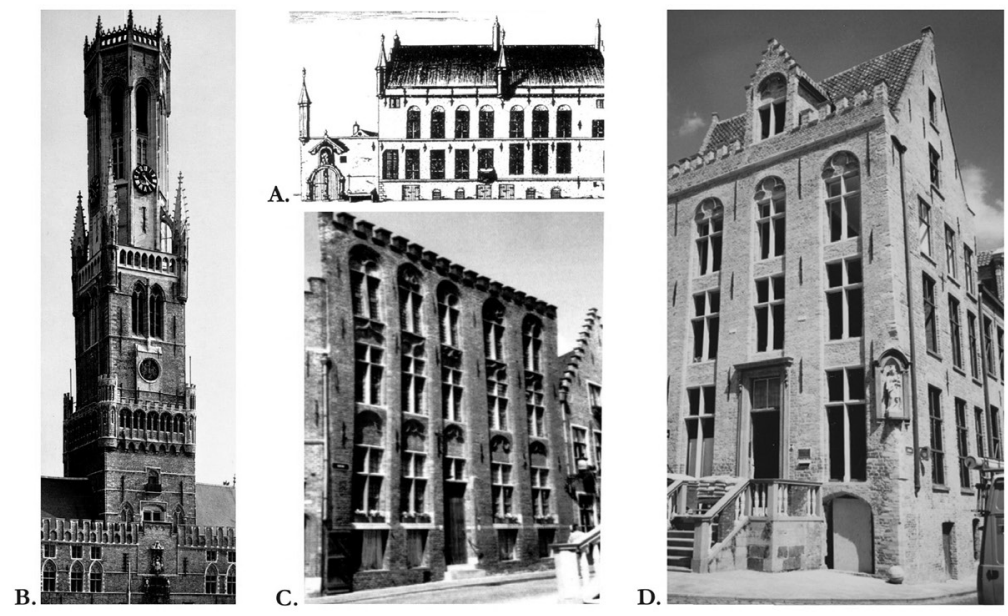

Il. 11

Il. 11 A - Brugia. Kantor Angielski. Koniec XIV w.; B - Brugia, wieża hal targowych, około 1300 r.; C - Brugia, przedstawicielstwo kupców genueńskich, około 1399 r.; D - Dom celny, 1. Poł. XIV w., fot. A wg E. Pilecka, Średniowieczne Dwory Artusa w Prusach, Toruń 2005, il. 50; B, C, D - E. Pilecka 